Submission ID: 43871

\title{
Features of Changes of the Properties of Reservoirs and Oil of Massive Reef
} Deposits of Volgograd Region

S.I. Chizhov (RITEK OAO), D.S. Sergeev (Branch of RITEK JCC - Volgogradneftegaz TPP), N.S. Sibileva* (LUKOIL-Engineering LLC), A.N. Stepanov (LUKOIL-Engineering LLC), M.A. Sibilev ("LUKOIL" PAO)

\section{SUMMARY}

The revealing of reguarlty of changes of reservoir properties (porosity) and formation hydrocarbon systems through the deposits height are of significant theoretical and practical interest for the massive (reef) deposits.Processing of the results of complex field-geophysical studies (porosity determination) through the wells of evlano-livensky horizon of Pamyatno-Sasovskoye field are selected and analyzed. In general, significant changes of reservoir properties of oil at the height of the deposits is not observed, however, in massive deposits with large floor oil-bearing porosity changes from the arched part of fluidmaster, the pressure saturation is changed by the same principle. 


\section{Особенности изменения свойств коллекторов и нефти массивных рифовых залежей Волгоградской области}

Н.С. Сибилева (ООО «ЛУКОЙЛ-Инжиниринг»)*, С.И. Чижов, к.т.н.(ОАО «РИТЭК» ), Д.С. Сергеев (филиал ОАО «РИТЭК»-ТПП «Волгограднефтегаз»), А.Н. Степанов, к.г.-м.н. (ООО «ЛУКОЙЛ-ВолгоградНИПИморнефть»), М.А. Сибилев (ПАО «ЛУКОЙЛ»)

Памятно-Сасовское месторождение открыто и введено в разработку в 1990г., приурочено к протяженному (более 15 км.) рифовому массиву евлановско-ливенскоого возраста. По величине запасов оно относится к крупным месторождениям, которые в настоящее время обеспечивают основную добычу нефти в Волгогардской области (70-75\%).

По структуре пустотного пространства тип коллектора евлано-ливенского горизонта в основном порово-трещинно-кавернозный. Массивная органогенная постройка представляет собой плосковершинный внутридепрессионный барьерный риф (1), который характеризуется наличием крутого внешнего (юго-восточного) склона, сложенного глубоководными осадками, и более пологого внутреннего (северо-западного) склона, представленного мелководными осадками (2). Вся толщина от кровли коллектора до водонефтяного контакта (ВНК) является эффективной, нефтенасыщенной. При этом этаж нефтеносности составляет 284,1м. (скв.11 Платовская), средняя нефтенасыщенная толщина 167,2 м. ВНК определен по данным опробования и обработки материалов геофизических исследований скважин (ГИС) на абсолютной отметке $-2578 \mathrm{M}$.

Для условий терригенных коллекторов с платформенными залежами обычно дифференцируют фильтрационно-емкостные свойства (ФЕС) по площади. При этом, подобное разделение значительно влияет на добычные возможности скважин. Для коллекторов с массивными залежами эти изменения не столь значительны, особенно при эксплуатации скважин с открытым стволом, дренирующих значительные по толщине продуктивные интервалы со вскрытием до 70\% нефтенасыщенной толщины продуктивных отложений.

Особый теоретический и практический интерес для массивных (рифовых) залежей Волгоградской области представляет выявление закономерности изменения пористости коллекторов и свойств пластовых флюидов по высоте залежей. Подобные исследования, по установлению изменчивости, проведены на территориях Чеченской республики для массивных залежей верхнемелового возраста было выявлено закономерное ухудшение коллекторских свойств от свода к крыльям и переклинальным частям складки. $(3,4)$ В верхней части залежи трещиноватость известняков в 5,9 раз больше, чем в нижней. При остановке скважин, находящихся в сводовой и присводовой частях, восстановление пластового давления происходило практически мгновенно. Время восстановления давления в приконтурных скважинах достигало нескольких суток. Отмечалось также закономерное увеличение коэффициентов светопоглощения нефти, характеризующих ее оптическую плотность от свода залежи к водонефтяному контакту. Рассматриваемые пластовые системы являются преимущественно нефтяными, переходного состояния, находящимися в трещиноватых и трещиновато-каверновых коллекторах на больших глубинах (до 6000 м) в жестких термобарических условиях (температуры - от 140-190 С, давление 50-90 мПа). Они формировались в результате миграции и разгрузки метастабильных газовых растворов, что вероятно, связано, со слабым проявление гравитационных и межфазных явлений в массовых трещиноватых резервуарах большой высоты. $(5,6)$.

При изучении закономерностей изменения пористости по разрезу пласта, к которому приурочена евлановско-ливенская залежь нефти Памятно-Сасовского месторождения использовалась пористость, определенная по результатам интерпретации данных ГИС. Проведена обработка результатов по 56 скважинам. Полученные 6414 определений пористости по 14 интервалам были подвергнуты обработке, и из рассмотрения были исключены интервалы с граничными значениями пористости (менее $2 \%$ ). Вся продуктивная толща от купольной части до флюидораздела нефть/вода разделена на равные интервалы толщиной 20 м. При этом самая высокая часть залежи имела первый интервал -(2293-2320 м)., так как учитывалось, что в этой части проведено минимальное число определений пористости. Самый нижний интервал 


\section{EAGE}

имел отметки -(2560-2578)м, при этом полагалось, что нижняя гипсометрическая отметка соответствует ВНК.

По скважинам, вскрывшими продуктивные отложения, число определений пористости в пределах выделенных интервалов изменялось в основном от 146 до 759 (за исключением первого верхнего интервала где было 36 определений). Полученные значения пористости распределялись по выделенным гипсометрическим интервалам, в пределах которых определялась средняя пористость. Затем по всем скважинам в пределах каждого гипсометрического интервала определялось среднее арифметическое значение пористости тср (табл. 1 рис. 1).

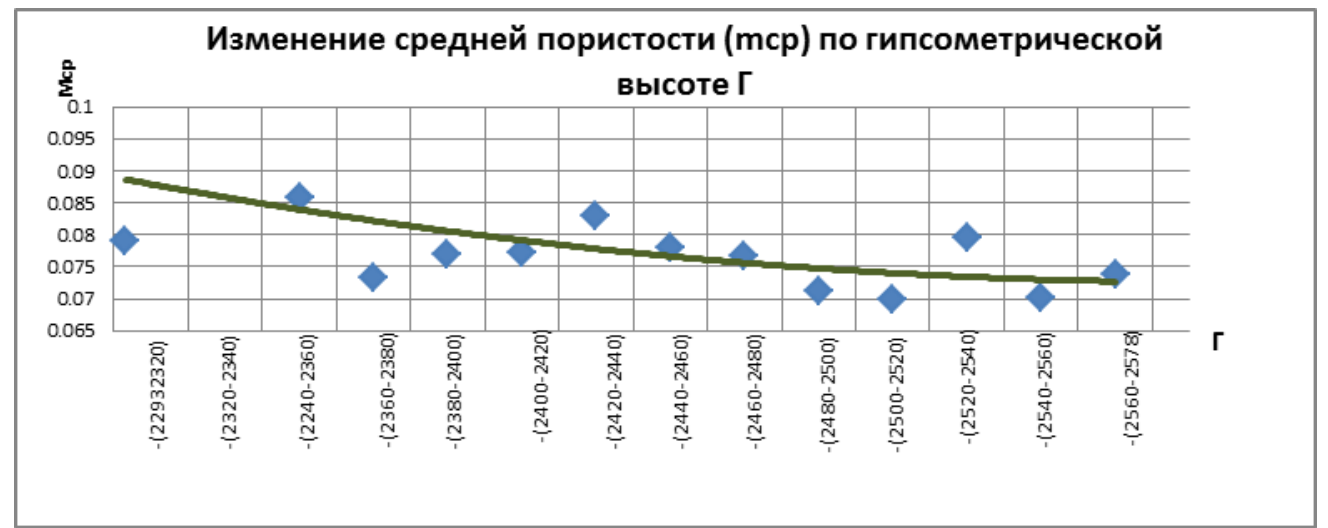

Рисунок 1. Изменение средней пористости по гипсометрической высоте

Как видно из рис.1 отмечается закономерное изменение средних арифметических значений пористости по гипсометрическим отметкам Г. Наименьшая средневзвешенная по толщине пласта пористость наблюдается в его нижних частях вблизи к ВНК.

Таблица 1.

\begin{tabular}{|l|l|l|l|}
\hline \multirow{2}{*}{$\begin{array}{c}\text { Гипсометрическая } \\
\text { отметка интервала, м. }\end{array}$} & $\begin{array}{c}|c| \\
\text { определение } \\
\text { пористости в } \\
\text { интервале. }\end{array}$ & $\begin{array}{c}\text { скважин, в которых } \\
\text { определялась } \\
\text { пористость }\end{array}$ & тср \\
\hline$(-2293-2320)$ & 36 & 4 & 0,0790 \\
\hline$(-2320-2340)$ & 146 & 14 & 0,1038 \\
\hline$(-2340-2360)$ & 410 & 25 & 0,0858 \\
\hline$(-2360-2380)$ & 596 & 32 & 0,0732 \\
\hline$(-2380-2400)$ & 672 & 37 & 0,0770 \\
\hline$(-2400-2420)$ & 744 & 40 & 0,0773 \\
\hline$(-2420-2440)$ & 759 & 40 & 0,0830 \\
\hline$(-2440-2460)$ & 618 & 36 & 0,0781 \\
\hline$(-2460-2480)$ & 509 & 35 & 0,0767 \\
\hline$(-2480-2500)$ & 496 & 29 & 0,0712 \\
\hline$(-2500-2520)$ & 502 & 26 & 0,0700 \\
\hline$(-2520-2540)$ & 384 & 55 & 0,0797 \\
\hline$(-2540-2560)$ & 266 & 21 & 0,0701 \\
\hline$(-2560-2578)$ & 256 & 18 & 0,0738 \\
\hline & & & \\
\hline & & 45 & \\
\hline
\end{tabular}

С уменьшением гипсометрических отметок пористость тср, несколько увеличивается. Несмотря на то, что средняя пористость вблизи ВНК имеет тенденцию к уменьшению она остается достаточно большой. При таких величинах коллекторские свойства продуктивных отложений обеспечивают высокие притоки пластовой воды из интервалов ниже 
первоначального ВНК. Хотя по данным, полученным в процессе разработки свидетельствуют о значительных размерах водоносной системы: по гидродинамическим расчетам ее объём превышает нефтеносный объем в 12 раз.

В связи с установленной закономерностью изменения пористости по высоте рифового массива Памятно-Сасовского месторождения определенный интерес представляет выявление наличие или отсутствие изменений свойств пластовой нефти по высоте залежи.

Всего на месторождении обработаны и проанализированы 53 глубинные пробы нефти из 24 скважин. При анализе результатов исследований из рассмотрения были исключены 18 глубинных проб, так как в них отмечались пропуски флюидов из пробоотборников или давление открытия клапана были значительно меньше, чем в среднем по остальным пробам, либо пробы отбирались на значительном расстоянии от интервалов дренирования. В целом, для рассмотрения были приняты результаты PVT исследований 35 глубинных проб. Скважины, по которым были проведены исследования, сравнительно равномерно распределены по площади. Интервалы отбора глубинных проб охватывают практически весь продуктивный разрез.

Для последующего анализа рассматривалось распределение по высоте залежи давления насыщения нефти газом, количество растворенного газа в пластовой нефти (газового фактора) и плотности нефти в пластовых условиях. Установлено, что выявленное уменьшение давления насыщения нефти газом по высоте залежи не зависит от времени отбора и анализа глубинных проб нефти. Зависимости количества растворенного газа в пластовой нефти и плотности нефти в пластовых условиях от гипсометрической отметки по высоте залежи не наблюдается.

Необходимо отметить, что глубинные пробы пластовой нефти отбирались и анализировались в разные периоды времени. Выявленное уменьшение давления насыщения нефти газом по высоте не зависит от времени отбора и анализа глубинных проб нефти.

В целом по массивным рифовым залежам нефти Волгоградской области с относительно большими этажами нефтеносности выявлено изменение пористости от сводовой части к флюидоразделу. Физико-химические свойства нефти изменяется по такому же принципу (давление насыщения нефти газом уменьшается от сводовой части к флюидоразделу).

\section{Выводы}

1. При оценке распределения запасов нефти необходимо учитывать изменение пористости по высоте залежи. Особую важность это обстоятельство имеет при оценке текущего коэффициента нефтеотдачи в заводненном объеме.

2. Для рифогенных залежей, в которых начально пластовое давление близко к давлению насыщения нефти газом, необходимо учитывать уменьшение давления насыщения нефти газом по высоте. При разработке таких залежей со снижением пластового давления в приконтурных частях может происходить развитие режима растворенного газа, в то время как в присводовых частях текущее пластовое давление будет выше давления насыщения газом.

\section{Список литературы}

1.Новые данные о распространении рифогенных формаций Волгоградского Поволжья, классификация рифов и вопросы методики их поисков /А.А.Новиков, В.П. Филиппов, В.М.Махонин// Геология, Геофизика и разработка нефтяных месторождений-1997-№12-С.4045 .

2.Бочкарёв В.А. Формирование органогенной постройки Памятно-Сасовского месторождения//Гр.ООО «Лукойл-ВолгоградНИПИморнефть».-2002-Вып.59.-С.73-78.

3.Лебединец Н.П. Изучение и разработка нефтяных месторождений с трещиноватыми коллекторами.-М.:Наука, 1997-398с.

4. Майдебор В.Н. Особенности разработки нефтяных месторождений с трещиноватыми коллекторами.М.:Недра, 1980.-288c.

5.Сейдж Б.Х. Термодинамика многокомпонентных систем -М.Недра,1969.-304с.

6.Степанов А.Н. Прикладные аспекты термодинамики гетерогенных систем //Гр. инта/ООО «ЛУКОЙЛ-ВолгоградНИПИморнефть». 


\section{References}

1. Novie dannie o rasprostranenii rifogennix formacij Volgogradskogo Povolzja, klassificaciya rifov i voprosi metodiki ix poiskov /A.A. Novikov, V.P. Filipov, V.M. Maxonin// Geologoya, Geofizika i razrabotka neftjanix mestorozdenij - 1997-№12-page.40-45.

2. Bochkarev V.A. Formirovanie organogennoj postrojki Pamyatno-Sasovskogo mestorozdenija // Gr.OOO «Lukoil-VolgogradNIPImorneft».-2002-Вып.59.-page.73-78.

3. Lebedinec N.P. Izytshenie i razrabotka neftyanix mestorozdenij $s$ trshinovatimi kollektorami.-M.:Nayka, 1997-398 page.

4. Maidebor V.N. Osobennosti razrabotki neftjanix mestorozdenij s treshinovatimi kollektorami.M.:Nedra, 1980.-288 page.

5. Seidz B.X. Termodinamika mnogokomponentnix system- M.:Nedra, 1969.-288 page.

6. Stepanov A.N. Prikladnie aspecti termodinamiki geterogennix sistem // Gr. In-ta/ OOO «Lukoil-VolgogradNIPImorneft». 